INDONESIAN JOURNAL OF

Clinical Pathology and Medical Laboratory

Majalah Patologi Klinik Indonesia dan Laboratorium Medik

\begin{tabular}{|c|c|c|c|c|c|}
\hline $\begin{array}{c}\text { IJCP \& ML } \\
\begin{array}{c}\text { (Maj. Pat. Klin. } \\
\text { Indonesia \& Lab. Med.) }\end{array}\end{array}$ & Vol. 17 & No. 3 & Hal. 127-177 & $\begin{array}{c}\text { Surabaya } \\
\text { Juli 2011 }\end{array}$ & $\begin{array}{c}\text { ISSN } \\
0854-4263\end{array}$ \\
\hline
\end{tabular}

Diterbitkan oleh Perhimpunan Dokter Spesialis Patologi Klinik Indonesia

Published by Indonesian Association of Clinical Pathologists

Terakreditasi No: 43/DIKTI/Kep/2008, Tanggal 8 Juli 2008 


\section{INDONESIAN JOURNAL OF \\ CLINICAL PATHOLOGY AND MEDICAL LABORATORY \\ Majalah Patologi Klinik Indonesia dan Laboratorium Medik}

\section{DAFTAR ISI}

\section{PENELITIAN}

Creatine Kinase Myocardial Band, Myeloperoxidase, Matrix Metalloproteinase- 9 dan Troponin T Pada IMA

(The Creatine Kinase Myocardial Band, Myeloperoxidase, Matrix Metalloproteinase-9 Activities and Troponin $T$ in Myocardial Infarction)

IA Hutagalung, I Patellongi, R Pakasi, M Arif, AA Mappahya, Hardjoeno

D-Dimer Penderita Sindrom Koroner Akut dan Stenosis

(D-Dimer in Acute Coronary Syndrome and Stenosis)

Birhasani, Lisyani BS, Ria T

Uji Hematologi Pasien Terduga Demam Berdarah Dengue Indikasi Rawat Inap

(Hematology Test of Dengue Hemorrhagic Fever on Suspected Patients Indicated for Hospitalization) Juranah, Darwati Muhadi, Mansyur Arif, Burhanuddin Bahar .

Imunokimiawi PGE2 Usus Ileum yang Kekurangan Energi Protein

(Immunohistochemistry of PGE2 Ileum Intestine Protein Energy Deficiency)

R. Heru Prasetyo

Gamma-glutamyltransferase dan Apolipoprotein B dengan Sindroma Metabolik

(Gamma-glutamyltransferase and Apolipoprotein B with the Metabolic Syndrome)

Tahono, M.I. Diah Pramudianti.

146-150

Umbi Ubi Jalar Ungu Bali (Ipomoea batatas) di Transaminase Serum, Malondialdehide Hepar dan Alkohol Kronis

(Balinese Purple Sweet Potato (Ipomoea batatas L) on SGOT, SGPT, MDA level and Chronic Alcohol) I Wayan Putu Sutirta-Yasa, I Made Jawi, Ida Bagus Ngurah, Anak Agung Ngurah Subawa.

Leukosit Infeksi Bakteri Sistemik

(Leucocyte in Systemic Bacterial Infections)

Meita Hendrianingtyas, MI. Tjahjati DM

Meningitis Tuberculosis

(Meningitis Tuberculosis)

Silvia Rachmayati, Ida Parwati, A Rizal, D Oktavia

Platelet Aggregation In Acute Coronary Syndrome

(Aggregasi Trombosit di Sindroma Koroner Akut)

Sulianty, Adi K Aman..

TELAAH PUSTAKA

Pemetaan Epitop dan Aplikasi Klinisnya

(Epitope Mapping and It's Clinical Aplication)

Jusak Nugraha.

LAPORAN KASUS

Infeksi Virus Rabies di Anak-anak

(Rabies Virus Infection in Children)

A.A.N. Subawa, DGD. Dharma Santhi, A.A Raka Sudewi, IWP. Sutirta Yasa 


\title{
PEMETAAN EPITOP DAN APLIKASI KLINISNYA
}

\author{
(Epitope Mapping and It's Clinical Aplication)
}

Jusak Nugraha

\begin{abstract}
Epitope mapping is one of the important findings in immunoIogy. The idea of systematic epitope mapping was first described by Geysen et al (Geysen et al., 1987a,b). This technic is further developed together with other important findings such as monoclonal antibody production, DNA recombinant, peptide synthesis and phage display of peptide or protein. The usage of this technic is to know the exact binding site of antigen with antibody or $T$ cell receptor, and can be used as the basic information to design a vaccine or diagnostic tools. The term epitope can be further classified as functional epitope, structural epitope, binding epitope, protective epitope, heavy infection epitope, neutralization epitope etc. In this article will be reviewed topics about epitope: $B$ and T cell epitope mapping technics using synthetic pin and its application.
\end{abstract}

Keywords: epitope, B cell epitope mapping, T cell epitope mapping, clinical applications

\begin{abstract}
ABSTRAK
Pemetaan epitop (epitope mapping) merupakan salah satu temuan cara yang penting di bidang imunologi. Awal pemetaan epitop yang tertata dikemukakan oleh Geysen et al.1,2 Teknik ini berkembang seiring dengan temuan penting lainnya seperti teknik pembuatan antibodi monoklon, ginabung ulang (rekombinan) DNA, pembuatan peptida, peptida transgenik dan phage display peptida atau protein. Kegunaan teknik ini adalah untuk mengetahui tempat ikatan antigen dengan antibodi atau dengan reseptor sel $\mathrm{T}$ terjadi, sehingga dapat dipakai sebagai dasar pembuatan vaksin ataupun dasar pembuatan perangkat/kit diagnostik tertentu. Istilah epitop dapat disebut pembatasan (dikualifikasikan) menjadi epitop berfungsi, epitop struktur, epitop pengikat, epitop pelindung, epitop infeksi berat, epitop penetral dan lain sebagainya. Dalam artikel ini akan ditelaah pemetaan epitop, teknik pemetaan epitop sel B dan sel T serta contoh penggunaan memakai pin buatan dan aplikasi klinisnya.
\end{abstract}

Kata kunci: Epitop, pemetaan epitip sel B, pemetaan epitop sel T, penerapan klinis

\section{PENDAHULUAN}

Molekul tertentu yang imunogenik dapat menimbulkan reaksi imunologis dengan baik respons imun humoral maupun imun sel. Beberapa syarat diperlukan oleh sebuah molekul agar dapat bersifat imunogenik, faktor yang berpengaruh antara lain: 1. Semakin besar ukuran molekul maka semakin imunogenik, tetapi untuk protein maka peptida dengan BM 4-5 kDa bersifat imunogenik. Yang terkecil dengan BM 2 kDa ada yang sudah imunogenik; 2. Letak epitop yang terjangkau di permukaan antigen. Makin terpajan makin besar daya imunogennya; 3. Derajad keasingan dari molekul tersebut; 4. Peran asam amino khusus di imunogenisitas.

Epitop adalah deretan/sekuens peptida (asam amino) yang khusus terdapat di permukaan antigen tertentu, yang berikatan dengan antibodi atau penerima sel T. Epitop yang berikatan dengan antibodi disebut 'epitop sel B', sedangkan yang berikatan dengan penerima sel T disebut 'epitop sel T'. Struktur tiga dimensi molekul imunoglobulin terlipat untuk membentuk permukaan yang menggenapi struktur permukaan tertentu antigen, yang disebut 'epitop'. Pemetaan epitop adalah kegiatan membuat untuk menentukan tempat ikatan antigen-antibodi dari antigen tertentu. Pembuatan ini juga dapat digunakan untuk menentukan tempat interaksi penerima dan pengikat (ligan), walaupun ini tidak berhubungan dengan sistem imun.

\section{PROSES PEMETAAN EPITOP}

Dari segi susunan asam aminonya epitop dikenal dua macam, yaitu: epitop continuous dan discontinuous epitopes. Continous epitope (penentu/ determinan antigenik) yang sesuai dengan pecahan peptida dari protein secara antigenik berhubungan dengan protein induknya Yaitu terdiri dari sejumlah sisa yang berurutan dalam deretan protein dan mungkin merupakan bagian dari discontinuous

Lab. Patologi Klinik FK Unair/RSUD Dr. Soetomo, Surabaya. E-mail: jusak.nugraha@yahoo.com 

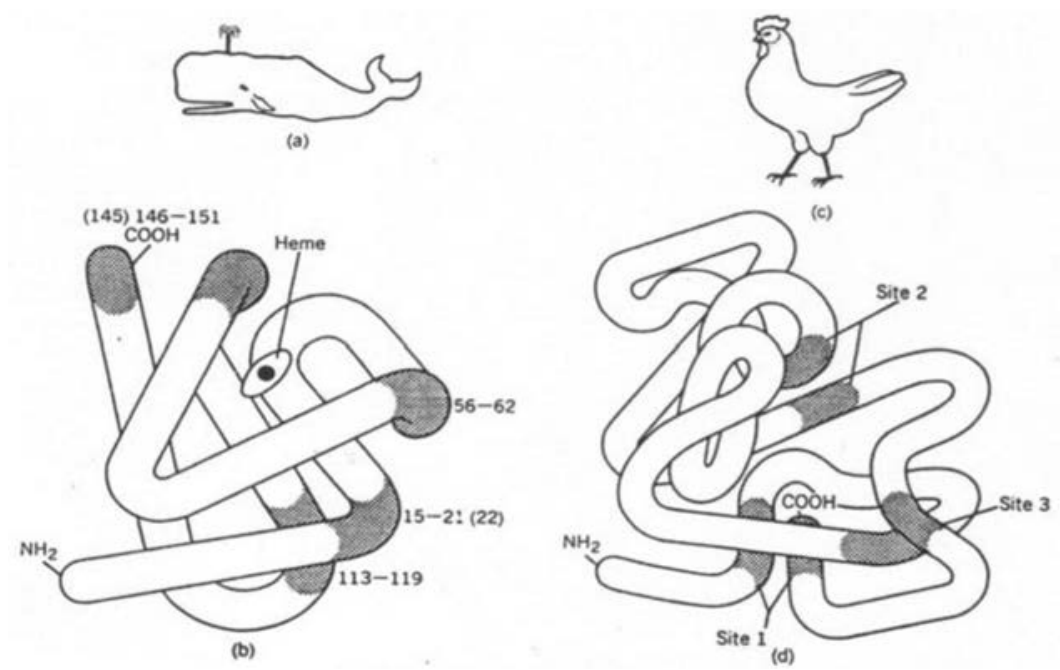

Gambar 1. Gambaran epitop linier dan epitop diskontinu. Gambar a \& b adalah protein sperm-whale myoglobin yang berepitop di bagian ujung pelipitannya dan merupakan epitop linier. Gambar c \& d adalah egg ovalbumin yang mempunyai 3 (tiga) epitop yang diskontinu yang dan terletak berdekatan dengan struktur tersiernya. ${ }^{3}$

epitopes yang lebih besar dan terdiri dari sisa yang berjauhan dalam runtunannya dan disatukan oleh lipatan rantai polipeptida. Bila tidak ada penjelasan lebih lanjut, istilah epitop biasanya dipakai untuk epitop sel B yaitu bagian antigen yang dikenal oleh penerima dan oleh antibodi. Jenis epitop yang kedua dikenal sebagai epitop sel T, yaitu pecahan peptida dari protein yang telah diolah dalam antigen presenting cell (APC) dan bersama-sama dengan molekul protein dari major histocompatibility complex (MHC) yang dikenal oleh penerima sel T. ${ }^{3}$

Ada tiga strategi dasar untuk mengenali epitop yang digunakan saat ini. Pendekatan yang pertama adalah dengan menggunakan ramalan alur (algorithms) untuk mengenali epitop yang dicurigai, membuat peptida yang mewakili dan kemudian dilakukan pengujian. Perkiraan daerah yang merupakan epitop ini berdasarkan keterikatan dengan air (hydrophilicity), keterjangkauan (accessibility), kelenturan (flexibility), keantigenan (antigenitas) dan struktur sekunder. Pendekatan ini dibatasi oleh kemampuan program yang dipakai untuk menentukan runtunan calon/kandidat dan juga deretan asam amino dari protein harus diketahui sebelumnya. Contoh beberapa program: Discotope analysis, 3D-Epitope-Explorer (3-Dex), "Syfpeithi" (University of Tübingen; www.syfpeithi.de) dan "BIMAS" (Bioinformatics and Molecular Analysis Section of the National Institutes of Health; bimas.dcrt. nih.gov/molbio) dan IEDB (Immune Epitope Database Analysis Resource; tools.iedb.org).4,5

Pendekatan kedua adalah membuat pecahan protein dengan cara enzimatik atau teknik DNA rekombinan dan ditunjukkan di Phage tertentu memakai teknik random peptide library on phage display. Bermacam-macam potongan peptida yang berada di permukaan faga tadi kemudian direaksikan dengan serum atau sel $\mathrm{T}$ pasien. Potongan yang reaktif dikenali dan kemudian dilakukan runtunan untuk mengetahui tempat epitop tertentu di protein. Runtunan seluruh protein tidak mutlak diperlukan di tahap ini dan urutan dari wilayah yang mengandung epitop dapat ditentukan kemudian.

Pendekatan yang ketiga adalah dengan menggunakan scanning epitope. Pada scanning epitope cara membuat pin diperlukan data urutan protein untuk membuat sejumlah peptida kecil yang umumnya tumpang tindih dalam runtunannya dan mewakili rentangan protein tertentu yang pendek dan secara bersama-sama merupakan runtunan asam amino yang lengkap protein (atau bagiannya yang menarik untuk ditentukan). Peptida kecil ini kemudian diuji sistem assay yang tepat dan epitop yang khas yang dikenali selanjutnya ditentukan. Scanning epitope merupakan pendekatan yang paling lengkap untuk mengenali epitop linier protein yang diketahui struktur utamanya. Di artikel ini hanya ditelaah pemetaan epitop dengan memakai pin peptida buatan. Pin buatan terbuat dari bahan dasar polietilen (polyethylene). Untuk penentuan epitop, peptida dibuat di inert polyethylene pins, tetapi mempunyai mahkota yang dapat dilepas dan dicangkokkan dengan asam akrilat melalui penyinaran. Pin ini dipegang oleh balok polipropilen (polypropylene) dan tersusun dalam bentukan dan ukuran yang sama bila ditangkupkan di lempeng mikrotitrasi (microtiter plate) yang mengandung 96 sumuran. Penyimpanan pin dilakukan dalam wadah tertutup yang diisi gel silika pada suhu $4^{\circ} \mathrm{C}$.

Pin bound peptide seperti Gambar 2 biasa digunakan untuk penentuan epitop sel B, sedangkan untuk epitop sel $\mathrm{T}$ dipakai peptida yang dapat dibelah (cleavable peptide). 


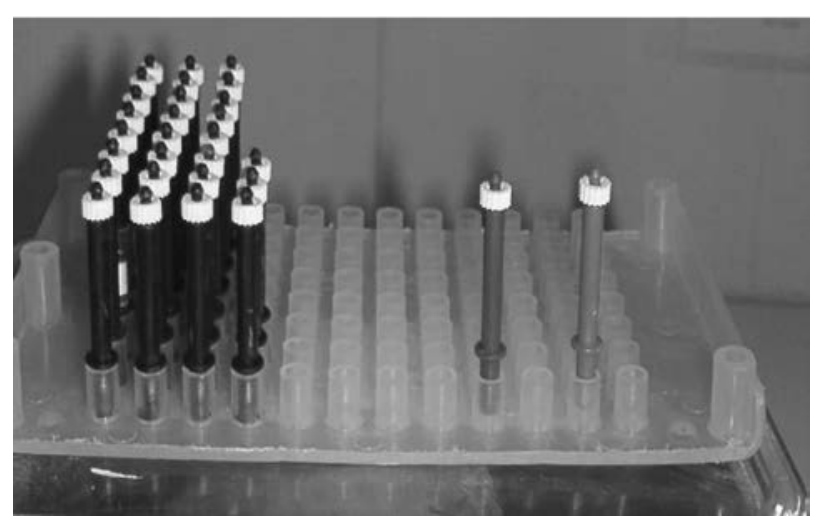

Gambar 2. Pin polyprophylene (warna hitam) dengan mahkota berwarna putih yang mengandung peptida buatan

Strategi untuk menganalisis epitop dengan jumlah sampel kecil dapat menggunakan cara batang polietilen (polyethylene rods) atau pins diikuti dengan cara ELISA yang berguna untuk mengenali epitop antibodi, dan sekarang dikenali sebagai teknologi Pepscan. Teknik ini terbentuk berdasarkan teknologi pin produksi Chiron Mimotopes, yang menghasilkan perangkat untuk epitope scanning dengan tiga sistem. Yaitu dua B-cells epitope scanning kit dan satu T-cell epitope scanning kit. Perangkat ini dapat digunakan dengan berbagai tatalangkah termasuk peptida bebas.

Panjang epitop (oligopeptida) yang dibuat untuk direaksikan berbeda-beda. Untuk penentuan epitop sel B dipakai peptide berderet dengan panjang 6-15-mer (asam amino). Yang sering dipakai biasanya 9-mer dengan pengimbang (offset) 1-mer dan saling menghimpit (overlapping) 8-mer.

Untuk penentuan epitop sel $\mathrm{T}$ dibedakan antara Sel T helper dan sel T sitotoksik.

a. Sel T CD4+: 12-15-mer. Dianjurkan 12-mer dengan offset 2-mer/13-mer dengan offset 3mer/11-mer dengan offset 1-mer.

b. Sel $\mathrm{T} \mathrm{CD8}{ }^{+}$: panjang rantai as amino 8-11-mer. Bila deretan asam amino yang akan dipetakan luas atau panjang, maka dipakai peptida yang lebih panjang untuk menentukan kedudukan wilayah yang reaktif. Sesudah itu baru diperhalus dengan menggunakan peptida 8-11-mer dalam wilayah tersebut. Strategi nyata ini diperlukan untuk lebih menghemat biaya.

Reaktivitas peptida buatan yang dipasangkan di pin diuji terhadap antibodi dalam serum manusia dengan menggunakan teknik ELISA, demikian juga dengan sitokin yang dihasilkan di dalam cairan terapung (supernantan) diukur dengan teknik ELISA. Jadi secara ringkasnya, teknik pemetaan epitop ini terdiri dari beberapa tahap. Mencari urutan asam amino dari Antigen yang akan jadi sasaran. Bila

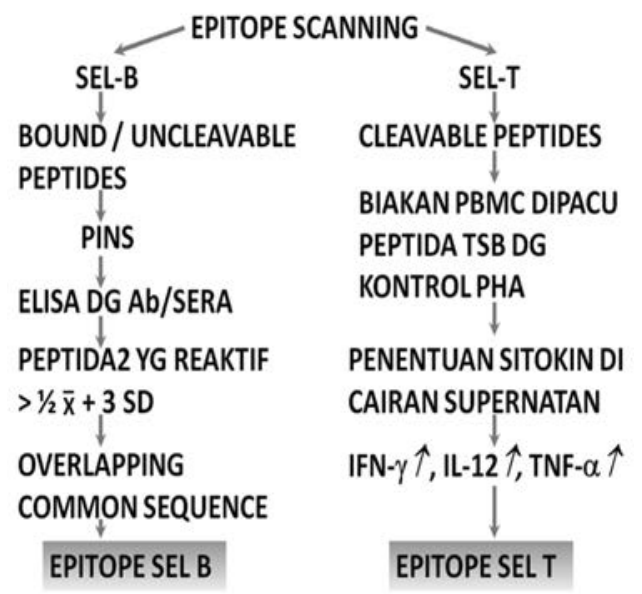

Gambar 3. Bagan pelaksanaan pemetaan epitop sel B dan sel $\mathrm{T}$ dengan peptida buatan.

belum diteliti oleh peneliti lain, maka ditentukan secara kasar dulu dengan membagi urutan asam amino Antigen tersebut menjadi potongan rantai asam amino yang panjang 20-30-mer \& offset $1 / 2$-nya. Antigen tersebut menjadi potongan rantai asam amino yang panjang 2030-mer. Dicari wilayah yang memberikan reaktivitas paling besar, misalnya pada ESAT-6 yaitu wilayah N-Terminus (urutan sisa 1-35) baik untuk epitop sel B maupun sel $\mathrm{T}$. Pemotongan urutan asam amino tersebut dengan program B-net komputer. Dapat dilakukan sendiri bila punya program atau bantuan dari perusahaan Chiron Mimotopes Australia.

Sintesis potongan asam amino buatan dengan teknik Geysen et al.1,2 memungkinkan pembuatan beratus-ratus peptida di batang/pins polietilen. Untuk penentuan epitop sel B dipakai bound/non-cleavable peptides di pins. Untuk penentuan epitop sel T dipakai cleavable peptides di pins. Sampai tahap ini pemetaan epitop sel T maupun sel B hampir sama, yaitu mencari pengenceran konjugat dan serum penderita yang terbaik, melalui proses optimasi. Dengan mereaksikan serum ataupun kontrol dengan potongan asam amino, dapat diketahui potongan peptida yang reaktif dan penilaian reaksi kontrol untuk pemantapan mutu.

\section{PEMETAAN EPITOP SEL B}

Belum ada tolok ukur kimia faali yang unik sebagai sifat yang khas dari epitop sel B. Sifat penting tertentu dari epitop adalah keterjangkauan yang diperlukan untuk dikenali oleh penerima sel B dan oleh antibodi. Peptida ini dapat dibuat dengan beberapa macam cara yaitu dengan cara berlandaskan resin (resin based), batang polietilen, atau pins.

Cara berlandaskan resin memerlukan waktu yang lama dan biaya yang mahal karena harus membuat peptida dalam jumlah yang banyak. Kemajuan yang 
penting dalam epitope scanning yaitu pengembangan teknik tertentu yang diuraikan oleh Geysen $\mathrm{dkk}^{1,2}$, yang memungkinkan pembuatan beratus-ratus peptida secara bersama-sama di batang polietilen atau pins yang diaktifkan. Teknik ciptaan Geysen dkk tersebut ialah 'multiple peptide synthesis'. Dewasa ini merupakan cara yang paling sering dipakai untuk menentukan epitop antibodi (B-cell epitopes) dengan menggunakan peptida yang tetap lekat di pins yang dapat dipakai ulang untuk pemeriksaan penentuan kadar berikutnya.

Di Indonesia telah dilakukan beberapa penelitian menggunakan teknik pemetaan epitop sel B ini. ${ }^{6-8}$ Sebagai contoh menerapkan penentuan epitop dari antigen ESAT-6 yang dilakukan oleh Nugraha ${ }^{7}$, setelah dilakukan ramal alur dan penelusuran pustaka maka ditentukan potongan antigen yang akan dipetakan yaitu dari wilayah $\mathrm{N}$-terminus asam amino 1-35. Kemudian dari Chiron Mimotopes dipesan 27 peptida yang menumpang tindih (overlapping peptide) yang masing-masing mempunyai panjang 9 asam amino sebagai berikut.

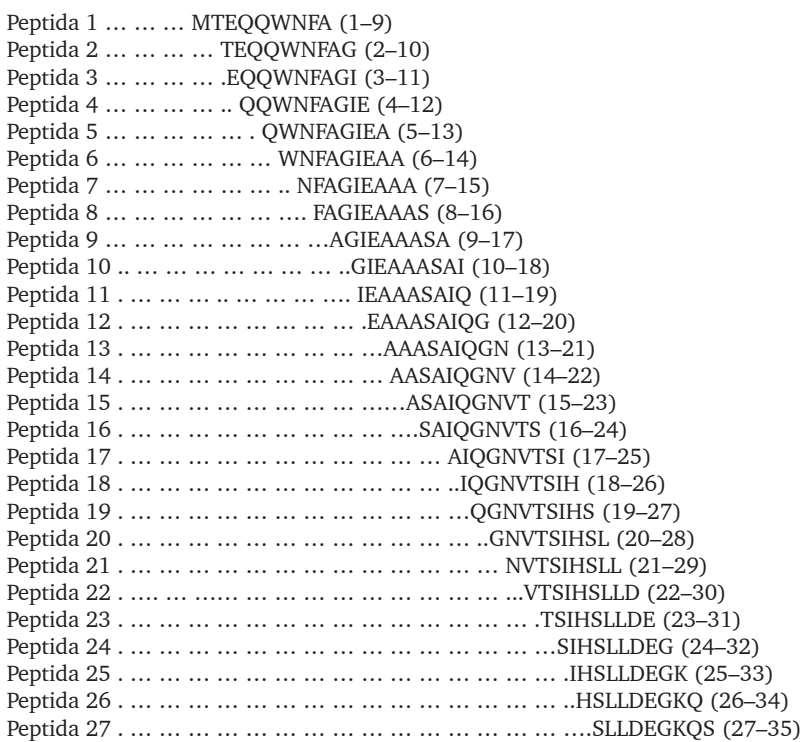

Ke-27 peptida tersebut telah dilapiskan di permukaan pin dan kemudian direaksikan dengan serum penderita TB dan perawat sehat yang merawat TB.

Hasil reaksi dengan serum penderita ini dianalisis dan ditentukan urutan saling tindih umumnya (overlapping common sequence)-nya, dengan cara menyusun peptida yang bereaksi positif kuat di atas cut-off.

\begin{tabular}{|c|c|c|c|c|c|c|c|c|c|c|c|}
\hline Peptida Nomer 22 & V & $\mathrm{T}$ & S & I & $\mathrm{H}$ & S & $\mathrm{L}$ & $\begin{array}{ll}\mathrm{L} & \mathrm{D}\end{array}$ & & & \\
\hline Peptida Nomer 23 & & $\mathrm{~T}$ & $S$ & I & $\mathrm{H}$ & S & $\mathrm{L}$ & L D & $\mathrm{E}$ & & \\
\hline Peptida Nomer 13 & & & S & I & $\mathrm{H}$ & S & $\mathrm{L}$ & L $\quad \mathrm{D}$ & $\mathrm{E}$ & G & \\
\hline Peptida Nomer 14 & & & & I & $\mathrm{H}$ & S & $\mathrm{L}$ & $\mathrm{D}$ & $\mathrm{E}$ & G & K \\
\hline $\begin{array}{l}\text { Overlapping common } \\
\text { sequence }\end{array}$ & & & & I & $\mathrm{H}$ & $S$ & $\mathrm{~L}$ & L $\quad \mathrm{D}$ & & & \\
\hline
\end{tabular}

Epitop IHSLLD ini kemudian dinamakan sebagai epitop infeksi berat, karena bereaksi kuat dengan serum mereka yang terpajan dengan kuman TB dalam frekuensi dan dosis yang berat, dan tidak bereaksi dengan orang sehat. Sebuah epitop paling sedikit terdiri dari 6 asam amino agar dapat berfungsi dengan baik. ${ }^{7}$

\section{PEMETAAN EPITOP SEL T}

Epitop sel $\mathrm{T}$ merupakan urutan peptida yang setelah berikatan dengan molekul MHC di antigen presenting cell $(A P C)$, diperlukan untuk pengenalan oleh penerima sel T yang khas. Melalui penggunaan peptida berderet yang epitopnya overlapping dapat dikenali melalui sitokin yang dihasilkan dengan cara yang tertata dan berurutan sedikit yang diperlukan untuk pengenalannya dapat ditentukan. Untuk pemetaan epitope sel $\mathrm{T}$ peptide dibuat di cleavable pin. Peptida dapat dilepas dengan menambahkan buffer steril dan peptida buatan ditambahkan di tatanan biakan sel T kemudian tolok ukur aktivasi sel $\mathrm{T}$ diukur. Cara ini setara dengan sel pinal/clone $\mathrm{T}$ dan sel $\mathrm{T}$ yang tidak murni seperti sel kelenjar getah bening dan PBMC. ${ }^{9}$

Pemilihan jenis peptida bergantung dengan jenis epitop yang akan ditentukan. Untuk sel $\mathrm{T} \mathrm{CD}^{+}$ helper, peptida dengan terminal $\mathrm{N}$ dan $\mathrm{C}$ yang dihalangi bekerja lebih tepat guna dibandingkan dengan peptida yang tidak. Terutama untuk peptida yang pendek (kurang dari 15 mer) untuk sel T CD8+ (sitotoksik) peptida dengan panjang 15 mer atau lebih dengan ujung terminal $\mathrm{N}$ dan $\mathrm{C}$ sangat tepat guna untuk menentukan awal tempat epitop. Namun, untuk penentuan lebih rinci, dengan menggunakan peptida yang lebih pendek (8-11 mer), harus digunakan peptida yang tidak dihalangi ujungnya. ${ }^{10}$

Cara kerja pemetaan epitop sel $\mathrm{T}$ dengan teknik penentuan kadar perangsang sel (Cellular Stimulation Assay) sebagai berikut:

Darah vena segar sebanyak $50 \mathrm{~mL}$ disiapkan, dan dimasukkan ke dalam $100 \mathrm{~mL}$ botol yang berisi glass beads, dalam keadaan sucihama kemudian dikocok 10 menit sampai beads diikat kuat oleh bekuan fibrin. Encerkan darah yang dipisah fibrinkan (didefibrinisasi) 1:1 dengan perantara tidak lengkap/ incomplete (RPMI) dan kemudian PBMC diasingkan dengan pemusingan di atas Ficoll-hipaque. Empat (4) lapisan dari bawah ke atas terjadi berurutan: sel darah merah, Ficoll-hipaque, buffy coat (PBMC), plasma/serum pisah fibrin (defibrinated plasma/ serum).

Buffy coat (PBMC) \& serum otologus terpisah dari yang lain. Serum otologus segera tidak diaktifkan pada $56^{\circ} \mathrm{C}, 30$ menit. PBMC dicuci $2-3$ kali dengan RPMI untuk menghilangkan Ficoll-hipaque, kemudian PBMC diampaikan ulang (resuspensi) 
dalam media "lengkap/complete" + 10\% v/v serum otologus + Penicillin/Streptomycin. Kepekatan PBMC disesuaikan dengan jumlah $1,1-1,5 \times 10^{6} \mathrm{sel} / \mathrm{mL}$ lalu sel dirangsang dengan peptida yang diuji, inkubasi dalam inkubator $\mathrm{CO}_{2} 37^{\circ} \mathrm{C}$ selama 4-6 hari. Setelah inkubasi, diambil supernatannya untuk ELISA sitokin (IFN- $\gamma$ ) setelah kurang lebih enam (6) jam, dan sisanya ditambah $20 \mu$ l perantara dan 0,25 $\mu \mathrm{Ci}$ tritiated thymidins lalu diukur dengan $\beta$ counter untuk mengetahui proliferasi limfosit. Sebagai cutoff value $=$ nilai pembanding tanpa peptida +3 SD. Kemudian dicari peptida dengan nilai di atas cut-off dengan kadar IFN- $\gamma$ /atau cpm yang tertinggi. Cara menilai epitop sama dengan pemetaan epitop sel $\mathrm{B}$, yaitu dengan menentukan overlapping common sequence. ${ }^{11}$

\section{PENERAPAN KLINIS}

1. Epitop Sel B

a. Untuk antigen dalam sel seperti TB (ESAT-6), dapat dipakai untuk diagnosis.

b. Untuk antigen luar sel seperti S. mutans, digunakan untuk mengvaksin pasif. ${ }^{13}$

2. Epitop Sel T

Dapat dipakai sebagai landasan pembuatan vaksin, misalnya vaksin DNA/vaksin yang dapat dimakan (edible vaccine). ${ }^{12,14}$

\section{DAFTAR PUSTAKA}

1. Geysen HM, Rodda SJ, Mason TJ, Tribbick G. Strategies for epitope analysis using peptide synthesis. J. Immunol. Methods 1987; 102: 259-274.

2. Geysen HM, Tainer JA, Rodda SJ et al. Chemistry of antibody binding to a peptide. Science 1987; 235: 1184-1190.

3. Pellequer, J.L., Westhof, E., and Van Regenmortel, M.H.V. Epitope predictions from the primary structure of proteins.
In Peptide antigens: A practical approach (ed. G.B. Wisdom), Oxford, Oxford University Press, 1994; 7-25.

4. Simanjuntak Y. T-cell epitopes of Mycobacterium tuberculosis antigen 85 complex potential for generating antibody: an immunoinfomatics study. Microbiology Indonesia 2009; 3(1): 47-50.

5. Juniastuti,Takako Utsumi, Victor Eko Nugrahaputra et al. Another novel subgenotype of hepatitis B virus genotype C from papuans of Highland origin. J. Med. Virology 2011; 83(2): 225-234.

6. Anita Y. Epitop region P (824-853) antigen I/II Streptococcus mutans serotype $\mathrm{C}$ yang reaktif dalam patogenesis carries gigi di Surabaya. Desertasi. Program Pascasarjana Univ. Airlangga, 2000; 72-74.

7. Nugraha J, Handojo I, Pang T.Urutan asam amino dari epitop region N-terminus antigen ESAT-6 sebagai marka diagnostik penyakit tuberkulosis aktif. Disertasi Program Pascasarjana Universitas Airlangga. 2004.

8. Kurdi FN. Urutan asam amino epitope sel B region $\mathrm{N}$-terminus antigen L-ESAT-6 sebagai sarana diagnostik penyakit kusta. Disertasi Program Pascasarjana Univ. Airangga. 2009.

9. Abu Salim Mustafa, Fatema Shaban. Mapping of Th1-Cell Epitope Regions of Mycobacterium tuberculosis Protein MPT64 (Rv1980c) Using Synthetic Peptides and T-Cell Lines from M. tuberculosis-Infected Healthy Humans. Med Princ Pract. 2010; 19: $122-128$

10. Rebecca Axelsson-Robertson, Frank Weichold, Donata Sizemore, Markus Wulf, Yasir A. W. Skeiky, Jerry Sadoff and Markus J. Maeurer. Extensive major histocompatibility complex class I binding promiscuity for Mycobacterium tuberculosis TB10.4 peptides and immune dominance of human leucocyte antigen (HLA)-B*0702 and HLA-B*0801 alleles in TB10.4 CD8+ T-cell responses. Immunology, 2009; 129: 496-505.

11. Iñaki Comas, Jaidip Chakravartti, Peter M Small, et al. Human T cell epitopes of Mycobacterium tuberculosis are evolutionarily hyperconserved. Nature genetics 2010; 42(6): 498-503.

12. Jonathan M. Gershoni, Anna Roitburd-Berman, Dror D. Siman-Tov, Natalia Tarnovitski Freund and Yael Weiss. Epitope mapping. The first step in developing epitope-based vaccines. Biodrugs 2007; 21(3): 145-156.

13. Salvador Eugenio C. Caoili. Immunization with PeptideProtein Conjugates: Impact on Benchmarking B-Cell Epitope Prediction for Vaccine Design. Protein \& Peptide Letters, 2010; 17: 386-398.

14. Handojo I. Pengembangan diagnosis dan pencegahan tuberkulosis melalui pemetaan epitope ESAT-6. Pidato Guru Besar FK Unair, Surabaya, 8 Februari 2003. 